\title{
COMPARATIVE ANALYSIS OF SECTORAL INNOVATION SYSTEM AND DIAMOND MODEL (THE CASE OF TELECOM SECTOR OF IRAN)
}

\author{
Mohammad Hosein Rezazadeh Mehrizi (I), Mohammad Pakneiat (2)
}

\begin{abstract}
:
Porter's model of Competitive advantage of nations (named as Diamond Model) has been widely used and criticized as well, over recent two decades. On the other hand, non-mainstream economists have tried to propose new frameworks for industrial analysis, that among them, Sectoral Innovation System (SIS) is one of the most influential ones. After proposing an assessment framework, we use this framework to compare SIS and Porter's models and apply them to the case of second mobile operator in Iran.

Briefly, SIS model sheds light on the innovation process and competence building and focuses on system failures that are of special importance in the context of developing countries, while Diamond model has the advantage of brining the production process and the influential role of government into focus, but each one has its own shortcomings for analyzing industrial development in developing countries and both of them fail to pay enough attention to foreign relations and international linkages.
\end{abstract}

Key Words: Sectoral Analysis, Sectoral Innovation System, Diamond Model, Telecom, Developing Countries, foreign relations

(I) PhD student of Science and Technology Policy. Management and Economics School. Sharif University of Technology- Iran (with cooperation of SPRU-University of Sussex-UK).Address: Management and Economics School,Teymuri St., Habibollahy St.,Azadi Av., Tehran, Iran. Phone number (Mobile): +98- 912 - 550- 47- 50. M.Rezazadeh-Mehrizi@sussex.ac.uk.

(2) High-Tech Center; Ministry of Industries \& Mines, I.R. Iran. Address (office): No: 6, 2nd street,Ahmad Qasir street, Beheshti Avenue, Tehran, Iran. Phone number (Mobile): +98- 912- 508- 46- 67.Pakneiat@gmail.com

* I am grateful to Professor Ed. Steinmuller for his constructive comments on earlier versions of this paper. 


\section{Introduction}

\section{Sectoral Models and its importance}

The analysis of economic activities in the macro and micro level came before the efforts for analyzing "industries". It might be argued that the main reason for sector-level analysis is the "lost" ring of chain which links firm level factors to macro (both national an international) economic conditions. Similar to other branches of economics, different schools, devoted some efforts to sectoral analysis. Broadly speaking, we can classify them into "main-stream" and "non-main-stream" views. In the mainstream economics, different models proposed in Industrial Organization (IO), such as Structure, Conduct, Performance model tried to bring their focus on the structure and dynamics of industries based on the main assumptions of main-stream economics. On the other hand, non-main stream sectoral models, usually, begin from criticizing main-stream assumptions and methods.

Needless to say, both approaches have their own merits and shortcomings in general sense, but either of them, shed light on some aspects of the reality of industries. In addition, choosing among different models is highly bound up with the aim of analysis, as well as the nature of industry and the broader context of that industry.

In the first part of this paper, we try to prepare a framework of criteria for assessing the appropriateness of a sectoral model in the context of developing countries and then we try to two widely used sectoral models (Diamond model proposed by Porter ((Porter M. 1990)) and Sectoral Innovation System (mainly articulated by Malerba ((Malerba F. 2004))) and).

\section{Comparative analysis framework}

It's easy to prepare a list of criteria for comparative analysis of sectoral models, but in a goal-oriented approach, we tried to classify them into a general inclusive framework.

From the "model building" and "system analysis" literature, we know that each model has its aim(s), assumptions, structure (components and relations) and functions (overall outcomes of model if it is run).

But this general framework could be used for comparing different sectoral model when we think that different models are useful for different "analysis goals" (such as description of industry structure and dynamisms, or prescription for improvement of some aspects of industry), for different "Industries" (for example different categories of industries identified in $\mathrm{Pa}$ - vitt Taxonomy (Pavitt K. 1984)) in different "contexts" (for example in developed or developing countries). In addition, from a practical point of view, the limitations of analysis process impose some other criteria that could be used for this assessment (such limited access to specific data, level of aggregation, limitation of time and resources and experts) which are out of the scope of this paper.

Based on this approach, we classify the assessment criteria into four main broad groups as:

a. Main question and goal of model

b. Pre-assumptions of model

c. Components and relation in model (Structural View)

d. Dynamics of model (behavioral View)

For the specific reason of comparing sectoral models, we divide these main categories into smaller ones based on the above contingency approach ("analysis goal", "industry specification" and "context of Industry"). So the final framework is as bellow:

\section{a. Main question and goal of model}

Any model is seeking for some main questions. In a general sense, the goal of sectoral models can be description and/or prescription some aspects of industries. For this reason, models, try to focus on some specific variables which are named and "unit(s) of analysis" that shows the focus of model. In a dynamic view, each sectoral model is useful for a certain time horizon (short, medium and long term). Finally, models are different based on their quantitative versus qualitative approach.

Based on these issues which are related to the goal and mission of model, in some models, there is no difference between different models, but other ones, try to consider the differences between different industries.

\section{b. Pre-assumptions of model}

For achieving the above goals and missions, each model, explicitly or implicitly, has some assumptions.

These assumptions are rooted in the theoretical origin of that model and these assumptions are generally about the "Industry" per se (such as the definition of Industry, and the "context" of Industry, in its broad meaning (including all social, economic, political, environmental and technological aspects).

\section{c. Components and relation in model (Structural View)}

From a structural view, each model has some components and tries to relate them in a consistent structure. These compo- 
nents could be abstract variables (such as export, FDI, Herfindahl index and agglomeration of industry in a specific region), as well as actual actors (such as research organizations, government agencies and firms) and activities (such as R\&D, production, innovation). But what is important here is that how these models consider non-economic factors (actors, relations and activities) as well as economic factors. However, for our purpose, it is important to know whether models try to distinguish between different categories of firms or not.

About the issues related to the environment of industry, it is important that models pay attention to the relation between different actors (both vertical and horizontal), relations between domestic and foreign factors (such as trade, mobility of human resources and R\&D alliances).

\section{d. Dynamics of model (functional View)}

Parallel with structural view, any model could be analyzed from a functional point of view. But what is important here for us is that sectoral models be able to explain main dynamics of any industry. These dynamics are different in terms of time (life cycle), scope (influence and importance) and nature.

For our purpose, it seems that models could be compared based on whether they can explain the "emergence" and "evolution" of industries, production and innovation activities, competition as well as cooperation, learning and capability building, and finally the co-evolution between factors within and outside the industry.

\section{Comparison of SIS and Diamond Model}

In this part, after a brief review of two main above models, we try to compare them based on the framework proposed in the previous section.

\section{a. SIS}

It can be argued that the main rationale for emergence of Sectoral innovation system model was the extensive differences between sectors in terms of "knowledge base", "actors" and "processes" ((Malerba F. 2004): 9). I brief, in the sectoral innovation system, tries to explain the creation, absorption, sharing and utilization of knowledge and innovation in a sector. This model can help us to have better understanding of Structure and boundaries of sectors, agents and their interactions, learning and innovation processes specific to a sector, types of sectoral transformation and factors at the base of the differential performance of firm and countries in a sector ((Malerba F. 2004): II).

This approach is rooted in two main theoretical bases: evolutionary economics and innovation system ((Malerba F. 2004): II) and "industrial organization" is the main tradition of SIS.

Based on this model, a sector is "a set of activities that are related by a set of product groups for a given emerging demand and share some basic knowledge"((Malerba F. 2004): 9-I0). The major components of a sector in this model are "knowledge and technology","actors and networks" ,"institutions" and "demand"((Malerba F. 2004): I0).

In terms of "knowledge base", this model assumes that often more that one technology exists in a sector and usually we face a Technology-Product matrix in any sector. These technologies are interdependent and complementary, and for innovative activities knowledge should be accumulated over time. This view believes that the main parameter that determines the boundaries of sectors is "the common knowledge base" and it can explain the differences between sectors in terms of "appropriability", "opportunity" and "accumulativeness". ((Malerba F. 2004): I2-14).

In SIS, actors are ranging from individual level to even a collection of organizations; the organizations include both "firm" (suppliers, producers and customers) and "non-firm" organizations (such as Universities, Financial institutions, Gov agencies, Trade unions, Technical associations). The main attributions of these actors are "Learning processes", "Competencies", "Beliefs”, “Objectives”, “Organizational structure”, "Behavior”. ((Malerba F. 2004): 24-26)

These actors are connected and interact through different kinds of linkages that include both "market" and "non-market" relations which can be summarized in five categories as "communication", "exchange", "cooperation", "competition", "command”. ((Malerba F. 2004): 24-26).

Another building block of SIS model is "institution". In short, Institutions are "the rules of game" (((North D., 1990 \#43): 7); (Edquist C. 2005): I82), such as Norms, routines, common ha-

\footnotetext{
I Éste sector está conformado por todas aquellas empresas que prestan los servicios de electricidad, agua corriente, gas natural y telefonía a clientes residenciales, comerciales e industriales.
} 
bits, established practices, rules, laws, standards. Institutions not only shape the action of actors, but also are shaped by the activities and interactions of actors. They include both formal and informal institutions, as well as national and sectoral ones.

Finally, demand is a heterogeneous collection of demand that could be attributed to "individual customers", "firms" and "public sector", which are characterized by knowledge, learning processes, competencies and goals and each is affected by social factors and institution.((Malerba F. 2004): 28-29)

SIS tries to provide a dynamic view of sectors by considering the process of "variety generation" and "selection" (borrowed from its evolutionary base). The variety generation could be done in terms of variety in "Products", "Technologies", "Firms", "Institutions", "Strategies and behaviors", through processes such as R\&D, innovation and creation of new actors. Both market and non-market selection processes try to reduce this variety. In a broad view, all these dynamisms result in co-evolution of different aspects of sectors (technology, actors, linkages, institutions and demand) over time.((Malerba F. 2004): 29-33)

\section{b. Porter's model}

In 1990, Michael Porter articulated his extensive empirical studies of different nations and different sectors in terms of a simple and highly influential model named as "Diamond Model" ((Porter M. 1990)). It is difficult to say that this model is "exclusively" a sectoral model because porter utilized it both for nations and sectors. It can be argued that his model is rooted in his academic background (management and main-stream economics) and this model could be assumed as an extension of his previous firm-level models (such as value chain and five forces). As mentioned by porter, the main concern (and may be the goal) of this model is to explain the impact of national conditions on the global competitiveness of industries.

As showed in figure I, diamond model is composed of four main mutually interacting dimensions as "Factor conditions", "Demand Conditions","Supportive and Related Industries" and "firm strategy, structure and rivalry", as well as two exogenous variables as "chance" and "government" that affect all other components.

In this model, all human resource, raw material, knowledge, capital and even infrastructures are assumed as factors. The "condition" of these factors (the quality, importance and even scarcity) is more important than the endowment and cost of them because it is possible that easy access to large amount of factors results in a kind of "inefficiency" of their utilization. More over, if other three dimensions are in a favorable situation for an industry, the pressure of competition would be high and the firms are committed to exist in the sector, this scarcity of factors could be constructive only if firms get the signal of this shortage well.

About the "demand condition", porter states that although, at least, a minimum amount of domestic demand is needed to help the industry to grow up, but the quality of this demand is more important than the quantity of that. By quality of demand, simply, porter means how sophisticated are features and specifications that customers (mainly domestic customers) expect. "Domestic" demand is more influential on the sector because the signals are get easier and more speedy by firms and the rich interaction between local demand and businesses heightens the process of interactive learning.

The third dimension of diamond model is supportive and related industries which interact (both horizontally and vertically) with the target sector. In a broad view, porter believes that cases of all over the world show that it is almost impossible to find only a single successful industry without strong and challenging supportive and related industries. The distinction between supportive and related industries helps this model to cover a large variety of inter-relations between different industries. Related industries are those that are some customers, production factors and/or technologies in common.

Finally, three main parameters of sector are encapsulated in the forth dimension of this model as "firm strategy, structure and rivalry". Porter believes that the strategy of firms (for example in terms of generic strategies as cost leadership, differentiation and so on (porter M. 1980)), the structure of industry (in terms of the distribution of size of firms) and the severity of rivalry, affect the competitiveness of the sector. Porter tries to include some non-economic factors (such as traditions and values that influence the motivation of firms for entering the sector) and the impact of spatial proximity in this dimension. Generally, he argues that the more firms are geographically close, the higher would be the rivalry, and the higher the rivalry, the better.

Including the role of government and all "unpredictable" parameters, porter adds two an exogenous components as "government" and "chance" respectively.All government initiatives like subsidize, education policies, quality standards, public procurement, taxation and anti trust laws are included in this component. Government as an intentional actor can play important role in this diamond."Catalyst" and "Challenger" are the cores of these roles. In this model, government has to avoid from any "direct" intervention in the market mechanism, but should try to improve competitive environment, and inspire firms to innovate. "Chance" is composed of factors (mainly external to the sector) that are not well predicted and (almost influenced by sector) such as new inventions, political decisions, wars, rapid 
changes in financial markets or other radical technical changes.

This model argues that if all these conditions go hand in hand in a proper dynamism, there will be a positive loop that grows sector more and more.The starting point for this loop could be the domestic demand, geographical agglomeration, local com- petition or supportive and related industries. But in short, the vital factor for continuity of this loop is the pressure of completion with a catalyst as local demand.

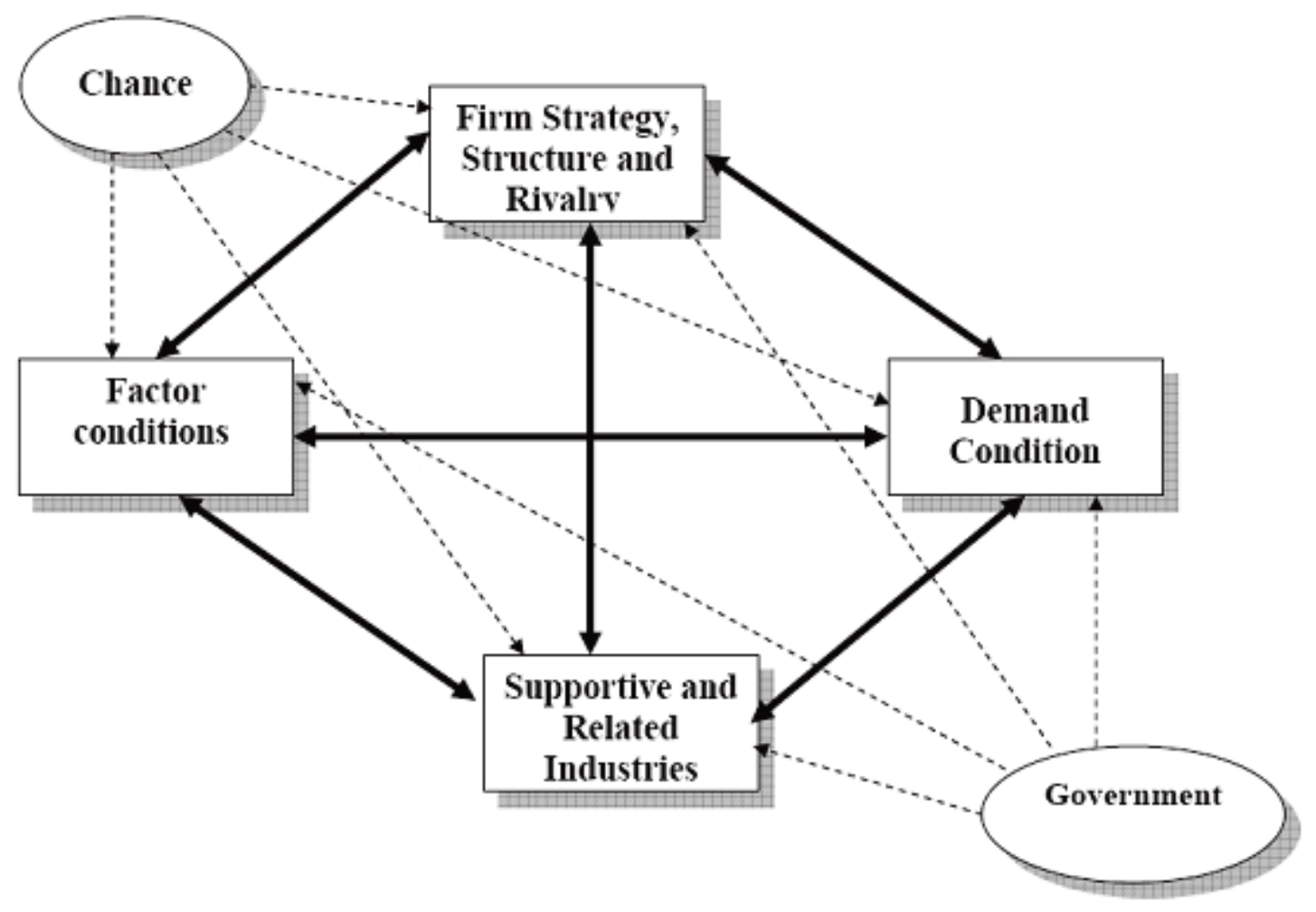

Figure I. Diamond Model

\section{c. Comparison of models based on assessment fra- mework}

Based on the above assessment framework and the brief explanation of each model, the comparison of models are mentioned in the table I as bellow. 
Table I: Comparative analysis of SIS and Diamond model

\begin{tabular}{|c|c|c|c|c|}
\hline $\begin{array}{l}\text { Criteria } \\
\text { Category }\end{array}$ & \multicolumn{2}{|l|}{ Criteria } & SIS model & Diamond model \\
\hline \multirow{6}{*}{$\begin{array}{c}3 \\
0 \\
\frac{0}{3} \\
0 \\
0 \\
0 \\
0 \\
\frac{0}{0} \\
0 \\
0 \\
0 \\
0 \\
0 \\
00 \\
0 \\
0 \\
0 \\
0 \\
3 \\
0 \\
0 \\
0\end{array}$} & \multicolumn{2}{|c|}{ The main question(s) } & $\begin{array}{l}\text { How innovation process }(=\mathrm{K} \text { creation, absorption, } \\
\text { distribution and utilization) take place in a sector? }\end{array}$ & $\begin{array}{l}\text { How national conditions influence international } \\
\text { competitiveness of industries? }\end{array}$ \\
\hline & \multicolumn{2}{|c|}{ Prescriptive and/or descriptive } & Both & Both \\
\hline & \multicolumn{2}{|c|}{ The main unit of analysis } & Firm / sector & Firm / sector / cluster \\
\hline & \multicolumn{2}{|c|}{ Time horizon } & $\begin{array}{l}\text { Medium / long term (in medium this model captures the } \\
\text { selection process but capability building and adaptation } \\
\text { process usually take place in long run) }\end{array}$ & $\begin{array}{l}\text { Medium/long term (the influence of each dimension on } \\
\text { other ones take place in medium term, but the evolution } \\
\text { of cluster takes } 10-20 \text { years) }\end{array}$ \\
\hline & \multicolumn{2}{|c|}{ Quantitative versus Qualitative } & Mainly Qualitative & Both \\
\hline & \multicolumn{2}{|c|}{$\begin{array}{l}\text { Considering differences between } \\
\text { industries }\end{array}$} & $\begin{array}{l}\text { By "technological regimes" which is related to the } \\
\text { "appropriability", "opportunity" and "accumulativeness" of } \\
\text { knowledge base }\end{array}$ & $\begin{array}{l}\text { Industries are different based on the degree of } \\
\text { dependency on "factor conditions" or "supportive and } \\
\text { related industries". Industries could be distinguished } \\
\text { based on the "structure of industry". But implicitly is } \\
\text { more relevant for "manufacturing" industries } \\
\text { (O'Donnellan 1994). }\end{array}$ \\
\hline \multirow{9}{*}{ 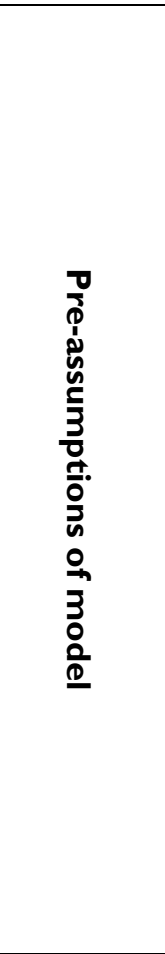 } & \multicolumn{2}{|c|}{ Theoretical origin } & Evolutionary economics and Innovation system & Main-stream economics and Management theories \\
\hline & \multirow{3}{*}{$\begin{array}{l}\text { Assumptions } \\
\text { about the } \\
\text { Industry }\end{array}$} & $\begin{array}{l}\text { the boundary of } \\
\text { industry }\end{array}$ & Is determined by "common knowledge base" & Is determined by common products \\
\hline & & $\begin{array}{l}\text { The size of } \\
\text { industry }\end{array}$ & No assumption & $\begin{array}{l}\text { (implicitly) assumes that industry is of noticeable share of } \\
\text { local demand }\end{array}$ \\
\hline & & $\begin{array}{l}\text { Differences } \\
\text { between firms }\end{array}$ & $\begin{array}{l}\text { Firms are different based on their knowledge base and how } \\
\text { firm accumulated knowledge and capability over time. }\end{array}$ & $\begin{array}{l}\text { Firms are different in terms of their different "strategies" } \\
((\text { Newman I978) and })\end{array}$ \\
\hline & \multirow{5}{*}{$\begin{array}{l}\text { Assumptions } \\
\text { about the } \\
\text { context of } \\
\text { Industry }\end{array}$} & $\begin{array}{l}\text { The role of } \\
\text { Government }\end{array}$ & $\begin{array}{l}\text { Government in this view is an active actor which evolves } \\
\text { such as other actors with its own limitations of capabilities, } \\
\text { which tries to compensate system failures }\end{array}$ & $\begin{array}{l}\text { Government should take role as facilitator and } \\
\text { challenger and tries to compensate market failures }\end{array}$ \\
\hline & & $\begin{array}{l}\text { Information } \\
\text { symmetry }\end{array}$ & $\begin{array}{l}\text { By considering the importance role of "tacit" knowledge, this } \\
\text { model doesn't rely on this assumption. }\end{array}$ & This assumption is the case in this model. \\
\hline & & $\begin{array}{l}\text { Rationality of } \\
\text { actors }\end{array}$ & Emphasizes on "bounded" rationality & Almost assumes complete rationality \\
\hline & & $\begin{array}{l}\text { Openness of } \\
\text { national economy }\end{array}$ & No assumption & Assumes this and prescribe so, as well. \\
\hline & & $\begin{array}{l}\text { Size and } \\
\text { development stage } \\
\text { of national } \\
\text { economy }\end{array}$ & No assumption & $\begin{array}{l}\text { (Implicitly) this model is more applicable for industries in } \\
\text { large and developed nation. }\end{array}$ \\
\hline
\end{tabular}




\begin{tabular}{|c|c|c|c|c|}
\hline \multirow{6}{*}{ 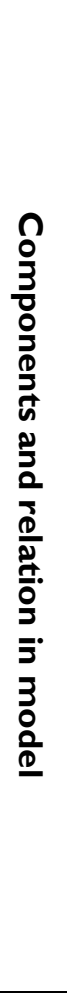 } & \multirow[t]{2}{*}{$\begin{array}{l}\text { within the } \\
\text { Industry }\end{array}$} & $\begin{array}{l}\text { Considering Non- } \\
\text { economic factors } \\
\text { (social and } \\
\text { political) }\end{array}$ & $\begin{array}{l}\text { In terms of institutions, non-market mechanisms and some of } \\
\text { non-firm organizations }\end{array}$ & $\begin{array}{l}\text { (implicitly are considered to some extent) in terms of } \\
\text { "chance" and some political action of government }\end{array}$ \\
\hline & & $\begin{array}{l}\text { Considering } \\
\text { Geographical } \\
\text { proximity }\end{array}$ & $\begin{array}{l}\text { Is analyzed as affects on the knowledge spillover and sharing } \\
\text { among different actors }\end{array}$ & $\begin{array}{l}\text { Is analyzes as facilitates information distribution as well } \\
\text { as "motivation" of firms (as heightens competition) }\end{array}$ \\
\hline & \multirow[t]{4}{*}{$\begin{array}{l}\text { Relation } \\
\text { with } \\
\text { external } \\
\text { factors }\end{array}$} & $\begin{array}{l}\text { Relation between } \\
\text { different industries } \\
\text { (within the } \\
\text { country) }\end{array}$ & $\begin{array}{l}\text { (implicitly and to some extent) are analyzed in terms of } \\
\text { knowledge flow between sectors }\end{array}$ & $\begin{array}{l}\text { Are considered in terms of supportive and related } \\
\text { industries. }\end{array}$ \\
\hline & & $\begin{array}{l}\text { Considering the } \\
\text { role of trade }\end{array}$ & Almost not & $\begin{array}{l}\text { In terms of factor conditions (import of factors and } \\
\text { technologies) and demand conditions (export of product } \\
\text { and services) but is not so capable to consider the } \\
\text { impact of foreign competitors on the domestic industries } \\
\text { ((Dunning 1993) and (Hodgetts 1993)) }\end{array}$ \\
\hline & & $\begin{array}{l}\text { Considering the } \\
\text { role of Foreign } \\
\text { Investment }\end{array}$ & Is analyzed from the point of view of knowledge transfer & $\begin{array}{l}\text { Almost can not consider this factor properly ((Rugman } \\
\text { 1985) and (Özlem 2002)) }\end{array}$ \\
\hline & & $\begin{array}{l}\text { Considering the } \\
\text { position of sector } \\
\text { in global value } \\
\text { chain }\end{array}$ & $\begin{array}{l}\text { The knowledge relations between local firms and global rivals } \\
\text { and the role of complementary knowledge assets and } \\
\text { capabilities determine the position of sector in the global } \\
\text { value chain. }\end{array}$ & $\begin{array}{l}\text { In this view, the position of local firms in international } \\
\text { value chain can be analyzed in the "supportive and } \\
\text { related industries", but the emphasis of this model on } \\
\text { "domestic" supportive and related industries leads to } \\
\text { paying insufficient attention to this point. }\end{array}$ \\
\hline \multirow[b]{2}{*}{ 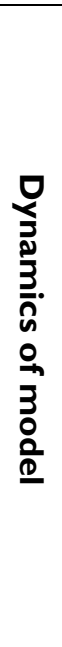 } & \multicolumn{2}{|c|}{ Emergence of new industries } & $\begin{array}{l}\text { Is explained by functions of innovation system in which first } \\
\text { of all, knowledge should be developed and then actors should } \\
\text { come to change this knowledge into economic values, } \\
\text { accordingly, the needed institutions will be built and the } \\
\text { industry evolves. }\end{array}$ & $\begin{array}{l}\text { Can be explained but empirically, is due to different } \\
\text { factors such as demand, supportive are related } \\
\text { industries, factor endowment or some initial successful } \\
\text { firms }\end{array}$ \\
\hline & \multicolumn{2}{|c|}{$\begin{array}{l}\text { The evolution of Industry and path } \\
\text { dependency }\end{array}$} & $\begin{array}{l}\text { Is analyzed based on the process of selection and variety } \\
\text { generation in the industry. Actors try to survive by being } \\
\text { adapted to new changes in the environment by "capability } \\
\text { building". Actors are path dependent and accumulate } \\
\text { knowledge over time } \\
\text { In this view, through the process of "adaptation", firms try to } \\
\text { learn by accumulation of knowledge and capability. On the } \\
\text { sector-level, the sectoral system tries to learn by changing } \\
\text { the capabilities of actors, creating new actors and changes in } \\
\text { the relations among them or by changing the institutions }\end{array}$ & $\begin{array}{l}\text { Is explained in terms of interaction between different } \\
\text { dimensions of diamond. The main mechanism of } \\
\text { selection is market selection and firms try to adjust their } \\
\text { strategies to adapt to changes in the environment } \\
\text { (changes in the structure of Industry and changes in } \\
\text { other dimensions). } \\
\text { In this view, the sector evolves based on the horizontal } \\
\text { (between firms, suppliers, supportive and related } \\
\text { industries, customers) and vertical (in terms of market } \\
\text { competition among firms) linkages. But it says nothing } \\
\text { about the capability building explicitly (Gray |99|). }\end{array}$ \\
\hline
\end{tabular}




\begin{tabular}{|c|c|c|}
\hline Capability building & Is mainly done by creation and acquisition of knowledge & $\begin{array}{l}\text { Is mainly created by better allocation of resources due } \\
\text { to the pressure of competition, and pays no direct } \\
\text { attention to competence building (Lundvall 1999). }\end{array}$ \\
\hline $\begin{array}{l}\text { Innovation (radical / incremental // } \\
\text { Process/product/) }\end{array}$ & $\begin{array}{l}\text { In this view, innovation is analyzed over its whole process } \\
\text { from knowledge creation and absorption to its utilization. All } \\
\text { kinds of innovation are considered and analyzed and the } \\
\text { influence of all actors, relations, and institutions on the } \\
\text { innovation process is analyzed. }\end{array}$ & $\begin{array}{l}\text { In this model, innovation is due to buying technology (as } \\
\text { a commodity which is one of production factors in that } \\
\text { "usually represents technology as a given set of factors' } \\
\text { combination, defined (qualitatively and quantitatively) in } \\
\text { relation to certain outputs" ((Dosi G., I } 982) \text { : I5I)) or } \\
\text { through information exchange between customers, } \\
\text { firms, suppliers and rivals. In this model, the emphasis is } \\
\text { not on the nature and types of innovation, but on the } \\
\text { forces that pushes firms to innovate. }\end{array}$ \\
\hline Production & $\begin{array}{l}\text { In this view, the production is considered as one stage in the } \\
\text { innovation process and the focus in on how firms translate } \\
\text { inventions into economic value. }\end{array}$ & $\begin{array}{l}\text { This model is mainly focused on the production process } \\
\text { in a sector from suppliers to customers. }\end{array}$ \\
\hline Competition between firms & $\begin{array}{l}\text { Competition is considered as one of market-based } \\
\text { interactions among firms (only one kind of relations) }\end{array}$ & $\begin{array}{l}\text { The main emphasis of this model is on the competition } \\
\text { among firms (part of "firm strategy, structure and } \\
\text { rivalry" dimension) and its main effect is that pushes } \\
\text { firms to be more competitive. }\end{array}$ \\
\hline Cooperation & $\begin{array}{l}\text { In this view rivals cooperation to bring "complementary } \\
\text { assets", knowledge and capabilities together. Vertical } \\
\text { cooperation is analyzed with regards to "learning by doing". } \\
\text { In addition, the cooperation between firms and non-firm } \\
\text { actors and among non-firm actors is considered as well. }\end{array}$ & $\begin{array}{l}\text { In this view, almost, we can consider cooperation } \\
\text { between rivals but this is highly blamed due to the } \\
\text { reason that decreases the strength of rivalry. But other } \\
\text { kinds of cooperation especially with supportive and } \\
\text { related industries are analyzed mostly based on market } \\
\text { mechanisms. }\end{array}$ \\
\hline $\begin{array}{l}\text { Co-evolution of internal and } \\
\text { external factors of industry }\end{array}$ & $\begin{array}{l}\text { Actors, relations and institutions in any sector evolve based } \\
\text { on changes in the national and international actors (for } \\
\text { example government), relations (for example political } \\
\text { relations with other countries) and institutions (such as } \\
\text { nations IPR laws). In other direction, the changes in the } \\
\text { actors, relations and institutions within the sector can alter } \\
\text { similar components in national and even international levels. }\end{array}$ & $\begin{array}{l}\text { The main influence of external environment on sector is } \\
\text { through supportive and related industries, as well as } \\
\text { foreign competitions. In addition, as the sectors grow, } \\
\text { other supportive and related industries would be } \\
\text { influenced. }\end{array}$ \\
\hline
\end{tabular}




\section{Toward a synthesized model for developing countries}

It can be argued that both SIS and Diamond model shed light on some aspects of the reality of sectoral development. From the view point of developing countries, SIS has these main advantages:

a. describes the capability building process and learning

b. focuses on the whole process of innovation in its broad definition and by considering different types (for example incremental innovations seems to be more influential for catching up countries)

c. highlights the institutional aspects of sectors and their evolution which are both influential and both fragile in developing countries

d. This approach tries to bring non-firm actors and non-market organizations into serious consideration, which are more influential in developing countries and non-economic factors that seem to be of high importance in the development of industries in developing countries can be easily considered in this view.

e. Its qualitative approach is more appropriate for developing context that hard formal data is rare.

f. The systemic view and taking market mechanism for granted, makes this approach more suitable for developing countries in which often the information symmetry and perfect competition are not the case. Moreover, as sectors in developing countries suffer from incomplete institutional arrangements, missing actors and relations, the focus of SIS on "system failures" is useful in that guides developing countries toward designing and building different parts of innovation systems (which are usually prepared and well designed in developed ones).

g. As sectors in developing countries are strongly affected by international issues (such as FDI, export and import, foreign rivals and ...) this approach provides better understanding of the position of sectors in the global value chain and the impact of evolution of those factors on the local firms as well as co-evolution between external and internal factors of industry.

h. The evolutionary perspective of SIS helps us to have better understanding of the history of sectors and its impact on the present and future evolution of actors and relations

i. Finally, this model considers the needs and rationales for cooperation between firms better.

On the other hand, SIS approach could be misleading in some cases in developing countries as a. Focusing on innovation in practice, might divert attention from some kinds of innovation related to better allocation of labor and capital to the economic activities which seems of special importance for developing countries at least at early stages of imitation.

b. Being confined with this approach might prohibit developing countries from "market formation" activities and divert their attention from the importance of competition among firms.

c. In this approach, the government has no central role and is considers one the non-firm actors. This view might overlook the special position and importance (at least at early stages of catch up process) in developing countries.

d. And finally, putting "innovation" at the centre of focus, might results in not paying enough attention to the production process and production systems.

e. Although SIS (and more generally, Innovation system) view considers all actors, relations and institutions in sectoral and national level, but there is nothing that "specifies clearly how the components interconnect and co-determine one another" (Lundvall, 1999: 66).

\section{Compared with SIS, Diamond model has its own merits of}

a. Considering national conditions and their influences on the sectoral development (in developing countries it seems that industries are strongly affected by national economic conditions) b. Trying to emphasize the role of factor conditions which are relevant in the majority of industries in developing countries. c. Shedding light on the role of firms' strategies in the development of sectors

d. Focusing on production (rather than innovation) which in short term (mainly at early stages of catch-up process), imitation is more the case than innovation).

On the downside, Diamond model could be inappropriate for analyzing sectors in developing countries because

a. This model put its emphasis on economic relations and the force of competition which are not of the same importance as in developed countries.

b. This model almost fails to consider the capability building and accumulation of knowledge and competencies over time, which is crucial for the process of learning (the path from imitation to innovation). Generally, in this model, innovation is mainly assumed as a "commodity" and product and there is less direct attention to its interactive nature of innovation as a "process".

\footnotetext{
I Éste sector está conformado por todas aquellas empresas que prestan los servicios de electricidad, agua corriente, gas natural y telefonía a clientes residenciales, comerciales e industriales.
} 
c. This view, the focus on market mechanism might divert attentions from the need for fixing "system failures" and institutional development in the national and sectoral level.

d. Its implicit assumptions about the industry (which should be of a minimum size) and domestic economy (which are assumed that are open and not small) makes this model not to be suitable for developing contexts.

e. In this model, by considering government as an exogenous variable, it is difficult to explain changes that local firms (especially big firms with their non-market relations with state in developing countries) make to government policies and structure. f. And finally, this model almost fails to capture the reality of influential role of international factors on the local sectors, especially in the "globalization" process, and accordingly it can hardly prepares a base for analyzing the position of local sectors in the global value chain.

\section{Case of "IranCell"}

Iran telecom industry had witnessed different changes over recent three decades.After Islamic revolution in 1979, and trough developing new "Constitution", telecom was explicitly regarded as sectors that must be governed by government as a public sector due to its fundamental role. As the process of economic changes continued and the overall public and institutional attitudes toward privatization strengthened, a distinction between "structural" and "operational" aspect of telecom industry made which allowed private sector to enter this sector in delivering telecom services. The main breaking point in this history was the emergence of second mobile operator (as a rival to first public operator) that is a case with different economic and political aspects that deserves to be investigated more.

First attempts to establish second mobile phone operating system goes back to closing months in 2003. This project what lunched under the privatization movement which was highly emphasized as one of the major directions of third 5 year development plan.

The first challenge was rooted in an influential law in Iran which is named as "the maximum utilization of domestic capabilities", in which in all industries the import of foreign products is allowed only when domestic companies would not be able to provide similar products, even with lower quality. Different interpretations of "domestic capabilities" by different politicians and dignitaries (ISNA, 2005 $\mathrm{a}^{2}$ ), made this challenge more serious that "to what extent, the implementation of second operator in Iran should be delegated to foreign companies, and to whom."

Another problem was due to other laws made it obligatory that the share holders of all "Iranian" consortiums must own, at least, 5 I percent of the total share. As in this case, the problems of "connectivity" and other issues made foreign companies reluctant to take part in such a consortium that they have not enough freedom to implement and operate their mobile network.

All above challenges could be explained by "institutional arrangements" in a sector, but, other limitations come into existence due to "political relations" with other countries. Economic sanctions imposed by USA, made it almost impossible for Iranian companies to cooperate with US and almost EU companies. This made the alternatives limited to few Asian and African companies and accordingly strengthened the bargaining power of them.

The winner of bid was a consortium shaped by Iranian companies $(30 \%)$ and TURKCELL (70\%). But this consortium could not start this project due to what we thinks are not explicitly mentioned in two above models, "political issues and foreign relations". Due to some political reasons, such as its relation with Israel and its insistence on at least $5 \mathrm{I}$ percent of total share, Iranian government bodies and some other political actors in Iran (such as parliament and council of experts) opposed TURKCELL, even when it established its office in Iran and kicked the process.

These political pressures increased when domestic companies actively lobbied to establish their capabilities. So after almost half a year, that consortium resolved and new bid was made and designed in the way that increases the chance of Iranian companies. But the result was again in favor of other Japanese, Chinese and other foreign companies. The final Solution was the second ranked company in the bid, that finally MTN (SouthAfrican Telecom Company) was chosen as the foreign part of that consortium, named as "IRANCELL".

Although the final portfolio of firms in IRANCELL was dominated by Iranian companies, the shortage of time and lack of enough domestic capabilities in telecom industry lead Iranian companies to import most of products from foreign companies that among them, Chinese companies were active players. Again, the sanctions and the comparative disadvantage of domestic companies, resulted in situation in which almost political relations shaped the implementation of second operator in Iran.

2 Mohammad Khani, Mohammad Reza, Head of Telecom Industry Syndication, Iran students News Agency, 2005 / 04 / 24, News Code: $8402-01209$ 
This story is still continuing in that recent new sanctions due to nuclear activities, has made the situation more severe. As US government warned all companies which are dealing with Iran to stop their activities, even companies who entered this consortium have faced new challenges to invest in Iran telecom industry.

\section{Conclusion}

The above analysis shows that both models should be used for explaining and analysis of sectors in developing countries, with regards to all their pros and cons. They can be used as complementary models in that SIS has comparative advantage in terms of considering the innovation-related issues (especially the interactive nature of innovation process (\{Lundvall, 1999:62)), competence building and development of actors, relations and institutions of innovation systems in these countries, while the Diamond model is more suitable for analyzing production-related and market-intensive aspects of sectoral development which are more the case in short run.

The case of Iran second operator in telecom industry could be analyzed by both models, but still something is missing. Based on Diamond model, the domestic demand of mobile communication is not only of its sufficient critical mass, but also has a high growth rate over recent years (figure 2). In terms of the quality of demand, the hunger for different sophisticated services (such as SMS) was evident. In addition, the rivalry between first operator and second operator provided sufficient pressure for both rivals to compete toward better competitive situations. In terms of factor conditions, the access to sufficient domestic human resources, requisite knowledge (especially in the mobile communication sector) and capital (due to the support of some big associations and investment companies such as "BONYAD MOSTAZAFAN") remained no doubt that this dimension of diamond model puts no pressure on the firm. Finally, in terms of supportive and related industries, some worries existed as the access to "international" suppliers of its hardware and software (especially billing and security systems) but as Porter emphasizes, the domestic supportive and related industries must be developed in an evolutionary way. What was missing here was the starting point for this evolution process that could hardly be found in domestic dimensions that are proposed by Porter, but was almost clear that foreign partner was one of the most efficient solutions.

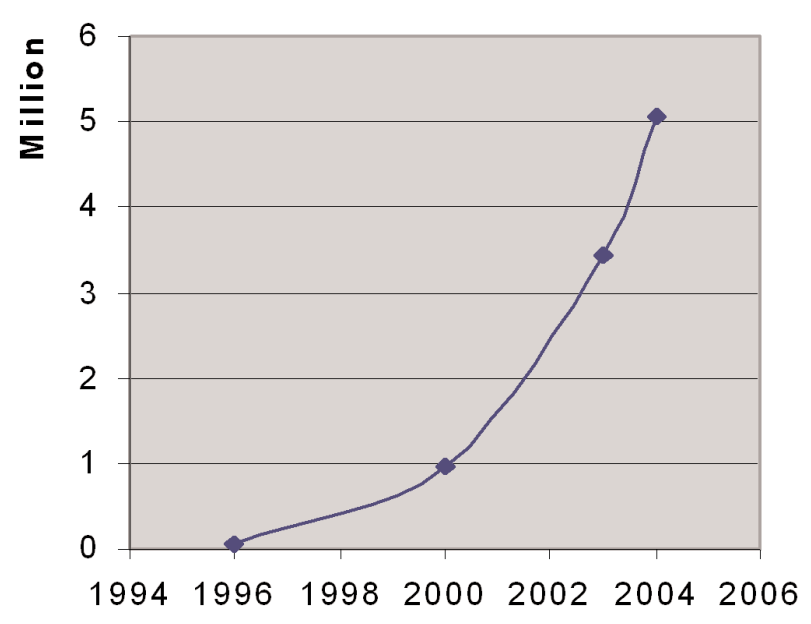

Figure 2. Changes in the mobile services in I. R. Iran (I996-2004) (ITC, 2004)

On the other hand, the SIS model draws our attention toward the knowledge base of telecom sector. As this project (Second operator) was almost the development of second mobile operator, it was composed of several different sort of technologies that some of them were so high-tech (such as billing systems and some switches and relays) that was hardly accessible by domestic firms through accumulating knowledge (in a reasonable period of time), but they were systematic and articulated enough to be accessed through foreign companies, especially when we consider that the opportunity for such technologies in
Iran was so high and at the same time there were almost no fear about of appropriability of knowledge by foreign companies, that all together made a favorable sector in terms of their entry.

With regard to actors and relations, there were no special worry about governmental agencies to support such a project, and also, private sector (especially for assembly and construction activities) had enough potential and wiliness to take part. The only anxiety was the relations between domestic actors and foreign companies, not in terms of "economic" and even 
"social" issues, but "political" considerations. Both previous economic sanctions and new ones due to Iran's nuclear activities had brought about a situation that most of foreign partners in almost all economic activities were reluctant to cooperate with Iran due to the fear of pressures imposed by U.S. and other European countries. However SIS model hardly captures the influence of political relations and bargaining powers between "nations" on the development of a sector like telecom in Iran. Admittedly, institutional aspect of SIS could shed some light on formal sanctions and international protocols that governed economic transactions with other countries, but two facts could be hardly explained by the this model. First, in terms of economic institutions, no fear was remained in terms of foreign relations with other parties, but the economic dominated view of institutional literature might overlook the political institutions (and mainly its informal ones). Second, although there were no formal and even informal "institution" that prohibits companies in China and some other countries to enter this project, the fear about political tensions with US was the main barrier to them for this reason, the fact that is hardly captured in terms of "institutional literature".

However, the above discussion shows that both models fail when we think about the importance of international factors and their impact on local firms (McKelvey, 1991 \#232). As the absorption of foreign knowledge is the core of learning innovation systems (Viotti 2002), and it is important for them to find their best position in the global value chain and promote that position, we recommend that both the above two models need to be completed with a sort of "outward" view that explicitly brings foreign relations into focus, what was highly influential in the case of second mobile phone operator in Iran. In this case, the porter's model could be pieced with political models of foreign relations in terms of relations among supportive and related industries, but in an "international" version of his diamond, and SIS could be integrated with such models both by extending its "actor-network" dimensions again far from the formal and economic and sector-specific ones, and by including political institutions not as secondary factors, but as main influential factors especially in the context of developing countries.

\section{Reference:}

DOSI G. (1982). "Technological paradigms and technological trajectories: the determinants and directions of technological change and the transformation of the economy." Research Policy II: |47-162.

DUNNING, J. (1993). "Internationalizing Porter's diamond. 2
33, pp. 8-I5 Special Issue (2)." Management international Review 33(2): 8-15.

EDQUIST C. (2005). systems of innovation: perspectives and challenges. The Oxford handbook of innovation. Fagerberg J. Mowery D. and Nelson R. R. Oxford, Oxford University Press.

GRAY, H. P. (I99I). "International Competitiveness: A Review Article " The International Trade Journal.

HODGETTS R M PORTER S DIAMOND FRAMEWORK

in a Mexican context Mantagement intebnational Beview

LUNDVALL, B.-A. (1999). "National Business Systems and National Systems of Innovation." Lundvall; International Studies of Management \& Organization 29.

MALERBA F., Ed. (2004). sectoral systems of innovation. Cambridge, Cambridge University Press.

MCKELVEY, M. (I99I). How do national systems of innovations differ?: a critical analysis of Porter, Freeman, Lundvall and Nelson. In: Hodgson, G.M., Screpanti, E.(Eds), Rethinking Economics: Markets, Technology and Economic Evolution, Edward Elgar, Aldershot: II7-137.

NEWMAN, H. (1978 ). "Strategic Groups and the StructurePerformance Relationship." The Review of Economics and Statistics 60(3): 4l7-427.

NORTH, D. C. (1990), Institutions, Institutional Change and Economic Performance, Cambridge: Cambridge University Press.

O'DONNELLAN, N. (1994). "Presence of Porter's Sectoral Clustering in Irish Manufacturing." Economic and Social Review 25(3): 22 I-232.

ÖZLEM, Ö. (2002). "Assessing Porter's framework for national advantage: the case of Turke." Journal of Business Research.

PAVITT K. (1984). "sectoral patterns of technical change: towards a taxonomy and a theory." Research Policy 13(6): 343-373. porter M. (1980). competitive strategy. New York, Free press.

PORTER M. (1990). the competitive advantage of nations. New York, Free press.

RUGMAN, A. a. J. M. ( 1985$)$. Megafirms: Strategies for Canada's Multinationals. Toronto, Methuen/Nelson. 
VIOTTI, E. B. (2002). "National Learning Systems:A new approach on technological change in late industrializing economies and evidences from the cases of Brazil and South Korea." Technological Forecasting and Social Change 69:653-680.

\section{About the Authors}

Mohammad Hosein Rezazadeh Mehrizi is the Ph.D. Student of Science and Technology Policy at Sharif University of Technology (Iran) with cooperation with University of Sussex (SPRU).After getting master of business administration (MBA), he has been confined his research and working experience to ICT industries, especially in developing countries. He has an experience of five years doing research on the industrial development of south-east Asia countries and more specifically on the development of ICT industries and their applications. His recent book named as "The role Information and Communication Technologies in the development of Knowledge Based Economies" is under publication as the result of these researches.

Mohammad Pakneiat holds an MBA degree from Sharif University of Technology, Tehran, Iran. He has been working as an advisor to several business and government organizations in Iran, which include Ministry of Industries \& Mines, Iran Khodro Auto Company, etc. His research interests include technology strategy formulation, technology policy (innovation systems framework) and technology development in developing countries. 